\title{
Cholesterol-lowering effect of policosanol on rabbits with hypercholesterolaemia induced by a wheat starch-casein diet
}

\author{
BY ROBERTO MENÉNDEZ, LOURDES ARRUZAZABALA, ROSA MÁS, ARMANDO \\ DEL RÍO, ANA M. AMOR, ROSA M. GONZÁLEZ, DAISY CARBAJAL, VIVIAN FRAGA, \\ VIVIAN MOLINA AND JOSÉ ILLNAIT \\ Department of Pharmacology, Center of Natural Products, National Center for Scientific Research, \\ PO Box 6880, Havana, Cuba
}

(Received 6 March 1996 - Revised 5 August 1996 - Accepted 22 August 1996)

\begin{abstract}
The effect of policosanol, a mixture of high-molecular-weight aliphatic alcohols isolated from sugarcane wax, on casein-induced hypercholesterolaemia in rabbits was studied. When policosanol was administered by the oral route once daily for $30 \mathrm{~d}(50 \mathrm{mg} / \mathrm{kg})$ the increases in plasma total cholesterol and LDL-cholesterol (LDC-C) were significantly reduced when compared with the control group. The incorporation of ${ }^{3} \mathrm{H}_{2} \mathrm{O}$ into sterols in the liver was significantly depressed, suggesting inhibition of hepatic cholesterol biosynthesis. The oral administration of policosanol raised the rate of removal of ${ }^{125}$ I-labelled LDL from serum. Kinetic parameters calculated following injection of $\left[{ }^{125} \mathrm{I}\right] \mathrm{LDL}$ showed than in casein-fed rabbits, the terminal half-life $\left(t_{1 / 2}\right)$ was significantly decreased after policosanol treatment. The hepatic LDL-binding activity was increased after policosanol administration which suggested that the enhanced clearance was due, at least in part, to increased receptor-mediated uptake of LDL by the liver. Considered together, these results suggest that policosanol can significantly reduce the increase of plasma LDL-C in rabbits fed on a wheat starch-casein diet by reducing cholesterol biosynthesis in the liver. Such an effect could account for the enhancement of LDL catabolism through the receptor-mediated pathway.
\end{abstract}

Policosanol: Hypercholesterolaemia: Cholesterol biosynthesis: LDL

Policosanol is a mixture of high-molecular-mass aliphatic alchohols isolated and purified from sugar cane (Saccharum officinarum L.) wax. Octacosanol $\left(M_{\mathrm{r}} 410.7\right)$ is its major component, followed by triacontanol $\left(M_{\mathrm{r}} 438.5\right)$ and hexacosanol $\left(M_{\mathrm{r}} 382.4\right)$ while other alcohols (tetracosanol, heptacosanol, nonacosanol, dotriacontanol and tetratriacontanol) are minor components.

Previous studies have demonstrated that serum cholesterol levels of pigs are significantly decreased by supplementation of the diet with policosanol (Cruz-Bustillo et al. 1991). Also, oral administration of policosanol decreases the serum cholesterol level in normocholesterolaemic rabbits (Arruzazabala et al. 1994), monkeys (Rodríguez-Echenique et al. 1994), healthy human volunteers (Hernández et al. 1993) and patients with hypercholesterolaemia (Pons et al. 1992, 1994; Aneiros et al. 1993, 1995; Soltero et al. 1993; Canetti et al. 1995; Castaño et al. 1995a,b; Torres et al. 1995).

Evidence has accumulated to support the hypothesis that policosanol inhibits cholesterol biosynthesis and enhances LDL processing. When cultured human fibroblasts were incubated with policosanol, $\left[{ }^{14} \mathrm{C}\right]$ acetate incorporation into total cellular cholesterol was inhibited. This inhibition was accompanied by increases in LDL binding, internalization and metabolism (Menéndez et al. 1994). In rats it was also found that 
policosanol inhibited cholesterol biosynthesis, because oral administration of policosanol decreased the incorporation of $\left[{ }^{14} \mathrm{C}\right]$ acetate into hepatic cholesterol (Menéndez et al. 1993).

It is reported that normal rabbits fed on a low-fat, cholesterol-free, semipurified diet containing casein become hypercholesterolaemic (Kroon et al. 1982; Khosla et al. 1991). Although the exact mechanism for this hypercholesterolaemia remains to be resolved, it is known that the hepatic LDL-receptor activity is reduced in rabbits fed on a wheat starch-casein diet (Chao et al. 1983; Samman et al. 1989; Khosla et al. 1991). Treating these rabbits with mevinolin, a highly potent inhibitor of cholesterol biosynthesis, prevents the increase in plasma and LDL-cholesterol. Such an effect is mediated through increased receptor-dependent catabolism of LDL by the liver (Chao et al. 1983).

In the current research we studied the effect of policosanol on hepatic cholesterol biosynthesis in New Zealand rabbits fed on a fat-free, casein-rich diet. We also studied the effect of policosanol on hepatic LDL-binding and the rate of removal of $\left.{ }^{125} \mathrm{I}\right] \mathrm{LDL}$ from serum.

\section{EXPERIMENTAL METHODS}

\section{Animals}

Young male New Zealand and White rabbits (2.26 (SD 0.28) $\mathrm{kg}$ ) were obtained from the National Center for Laboratory Animal Production (CENPALAB, Havana, Cuba). The rabbits were maintained on rabbit chow supplied by CENPALAB and feeding was restricted to $100 \mathrm{~g} / \mathrm{d}$ per animal (Canadian Council of Animal Care, 1980). They were housed in individual cages and adapted to laboratory conditions for $15 \mathrm{~d}$ before being transferred to the semipurified diet containing casein, the consumption of which was similar to those described by Kroon et al. (1982) ( $/ \mathrm{kg}$ ): wheat flour 333, cellulose 300, casein 270 , water 20 , maize oil 10, mineral mixture 7 . Semipurified diet consumption was restricted to $100 \mathrm{~g} / \mathrm{d}$ per animal (Kroon et al. 1982).

Animals were randomly distributed into two experimental groups (fifteen animals per group) according to their cholesterol levels and were fed on the diet for $30 \mathrm{~d}$. Policosanol $(50 \mathrm{mg} / \mathrm{kg}$ body weight $(\mathrm{BW})$ ) was orally administered as a suspension in a Tween 20 water vehicle $(1 \mathrm{ml} / \mathrm{kg} \mathrm{BW})$ for $30 \mathrm{~d}$. Control rabbits were given the same volumes of Tween 20-water vehicle. Body weights were recorded on a weekly basis. Fresh food and water were provided daily. All the animals were observed at least once daily to evaluate their health status.

\section{Lipid profile determinations}

Blood was drawn from the marginal ear vein on days 0,15 and 30 of treatment. Total cholesterol and triacylglycerol concentrations in serum and lipoproteins were assayed enzymically using diagnostic kits (Boehringer, Mannheim, Germany). Plasma lipoprotein fractions were obtained by a one-step density-gradient ultracentrifugation technique as described by Terpstra et al. (1981). The samples were centrifuged at $20^{\circ}$ for $24 \mathrm{~h}$ at 40000 $\mathrm{rev} . / \mathrm{min}$ in a Beckman L-7 ultracentrifuge (Beckman Instruments Inc., Spinco Division, Palo Alto, CA, USA) using a SW 41Ti rotor. 


\section{Effect of policosanol on in vivo cholesterol biosynthesis}

Experiments were carried out according to Spady \& Dietschy (1983). In the present experiment five animals from the control and treated groups were used. Newly synthesized cholesterol was measured in liver after injection of ${ }^{3} \mathrm{H}_{2} \mathrm{O}(7.4 \mathrm{MBq})$. At $60 \mathrm{~min}$ after injection rabbits were killed by exsanguination and livers were collected. Samples were cut into at least three slices (2-3 mm thick) and the lipids were saponified by incubating in alcoholic $\mathrm{KOH}$ for $2 \mathrm{~h}$ at $100^{\circ}$. Non-saponifiable lipids were extracted into hexane, and digitonin-precipitable sterols (DPS) were obtained. The specific activity (SA) of body water and the rate of hepatic sterol synthesis were calculated according to the method of Jeske \& Dietschy (1980). Cholesterol biosynthesis was expressed as nmol ${ }^{3} \mathrm{H}_{2} \mathrm{O}$ incorporated into DPS per $\mathrm{h}$ per $\mathrm{g}$ tissue (nmol/h per $\mathrm{g}$ ).

\section{Preparation and labelling of lipoprotein}

Before the metabolic and binding studies, blood was obtained from the marginal ear vein of unanaesthetized animals in the fasted state. Plasma was separated and LDL $(1.019<\rho<1.063 \mathrm{~g} / \mathrm{ml})$ from wheat starch-casein-fed rabbits was isolated by sequential flotation at $4^{\circ}$ using a Ti60 rotor in a preparative Beckman ultracentrifuge as described by Havel et al. (1955). Purified LDL was iodinated to a specific activity of 150-200 disintegrations/min (dpm)/ng using a modification of the ICl method of McFarlane (1958). The tracer contained less than $2 \%$ as free I as determined by precipitation with TCA.

\section{Effect of policosanol on the removal of $\left[^{125} I\right] L D L$ by intact rabbits}

Animals were fasted for $12-16 \mathrm{~h}$ before the kinetic study. ${ }^{125}$ I-labelled-LDL (SA 100-200 counts/min $(\mathrm{cpm}) / \mathrm{ng}$ protein) was injected into control and policosanol-treated rabbits (four animals per group, approximately $148 \mathrm{KBq}$ per animal) through the marginal ear vein. The amount of protein injected per animal was about $0.05 \%$ of the circulating pool of LDL protein. Blood samples were drawn from each rabbit at different time intervals for $42 \mathrm{~h}$. The [ $\left.{ }^{125} \mathrm{I}\right] \mathrm{LDL}$ contained in $500 \mu \mathrm{l}$ samples of serum was precipitated with TCA $(50 \mathrm{ml} / \mathrm{h})$. Radioactivity of the precipitated LDL in the samples was measured with a gamma counter (Miniganma, Pharmacia LKB Biotechnology, Uppsala, Sweden) and was expressed as a percentage of that precipitated from the sample taken $5 \mathrm{~min}$ after injection of the labelled LDL. The plasma radioactivity decay curves fitted a two-compartment model and the terminal elimination rate constant $(\beta)$ was estimated by linear regression of the logplasma concentration $v$. time curve (see Fig. 2). Plasma elimination half-life $\left(t_{1 / 2}\right)$ was determined from $\beta$, by the relationship $t_{1 / 2}=0.693 / \beta$ (Notari, 1980).

\section{Effects of policosanol on $\left[^{125} I\right] L D L$ binding in liver homogenates}

The heparin-sensitive binding of LDL to liver-tissue homogenates was determined with a filter assay as described by Rudling \& Peterson $(1985 a, b)$. The results, expressed as ng $\left[{ }^{125} \mathrm{I}\right] \mathrm{LDL}$ bound/mg protein, represent heparin sensitive binding calculated by subtracting the radioactivity of the filters incubated with heparin (heparin-resistant binding) from the radioactivity of the filters incubated in the absence of heparin (total binding). The nonspecific (heparin-resistant) binding was about $50 \%$ of the total binding and the CV of the assay was $12 \%$. Protein determinations were done according to Lowry et al. (1951). 


\section{Statistical analysis}

Comparisons between control and treated animals were performed using the nonparametric Mann-Whitney $U$ test.

\section{RESULTS}

As can be seen in Table 1 there was a similar weight gain in all the groups. Table 2 lists the lipid profile values during the study. At day 0 there were no significant differences between groups. Control animals maintained on the casein diet had increases in serum total and LDL-cholesterol (LDL-C) over the $30 \mathrm{~d}$ period. Although animals treated with policosanol also showed increases in these variables, the values attained were significantly lower than those of the control rabbits. The hypercholesterolaemia exhibited by the control rabbits fed on the casein-wheat starch diet was mainly related to increases in the LDL-C fraction.

The effect of policosanol on hepatic cholesterol synthesis is illustrated in Fig. 1, which shows the content of newly synthesized sterol in the liver of control and treated animals. There was a significant decrease in the content of $\left[{ }^{3} \mathrm{H}\right] \mathrm{DPS}$ in liver of the treated animals compared with the controls.

Table 1. Body weights $(\mathrm{kg})$ of rabbits fed on a casein-containing diet, at different times during the experiment

(Mean values and standard deviations for fifteen animals per experimental group)

\begin{tabular}{|c|c|c|c|c|c|c|}
\hline \multirow{2}{*}{$\begin{array}{l}\text { Day of expt... } \\
\text { Treatment }\end{array}$} & \multicolumn{2}{|c|}{0} & \multicolumn{2}{|c|}{15} & \multicolumn{2}{|c|}{30} \\
\hline & Mean & SD & Mean & SD & Mean & SD \\
\hline Control & $2 \cdot 30$ & 0.24 & 2.55 & 0.25 & 2.76 & 0.24 \\
\hline Policosanol & $2 \cdot 27$ & 0.30 & 2.49 & 0.27 & 2.72 & 0.30 \\
\hline
\end{tabular}

Table 2. Effects of policosanol on the serum lipid profile in rabbits fed on a wheat starchcasein diet $\dagger^{\dagger}$

(Mean values and standard deviations for ten animals per group)

\begin{tabular}{|c|c|c|c|c|c|c|}
\hline \multirow{2}{*}{$\begin{array}{l}\text { Day of expt... } \\
\text { Treatment }\end{array}$} & \multicolumn{2}{|c|}{0} & \multicolumn{2}{|c|}{15} & \multicolumn{2}{|c|}{30} \\
\hline & Mean & SD & Mean & SD & Mean & SD \\
\hline \multicolumn{7}{|c|}{ Total cholesterol $(\mathrm{mmol} / \mathrm{l})$} \\
\hline Control & 1.54 & 0.35 & 3.63 & 0.70 & 8.00 & 0.80 \\
\hline Policosanol & 1.53 & 0.40 & $2 \cdot 46^{*}$ & 0.70 & $5 \cdot 21^{*}$ & 0.79 \\
\hline \multicolumn{7}{|c|}{ LDL-cholesterol (mmol/1) } \\
\hline Control & 0.43 & $0 \cdot 10$ & 3.02 & 0.32 & $6 \cdot 52$ & 0.45 \\
\hline Policosanol & 0.40 & 0.11 & 1.77 & 0.23 & $4.03^{*}$ & 0.33 \\
\hline \multicolumn{7}{|c|}{ HDL-cholesterol (mmol/1) } \\
\hline Control & 0.52 & 0.10 & 0.46 & $0 \cdot 14$ & 0.74 & $0 \cdot 34$ \\
\hline Policosanol & 0.54 & 0.22 & 0.45 & 0.24 & 0.82 & $0 \cdot 16$ \\
\hline \multicolumn{7}{|c|}{ Triacylglycerols (mmol/) } \\
\hline Control & $1 \cdot 19$ & 0.31 & 1.25 & 0.90 & $1 \cdot 13$ & 0.22 \\
\hline Policosanol & 1.43 & 0.98 & 1.09 & 0.50 & 1.24 & 0.42 \\
\hline
\end{tabular}

* Mean values were significantly different from those for controls, $P<0.05$ (Mann-Whitney $U$ test).

+ For details of diet and procedures, see pp. 924-925. 


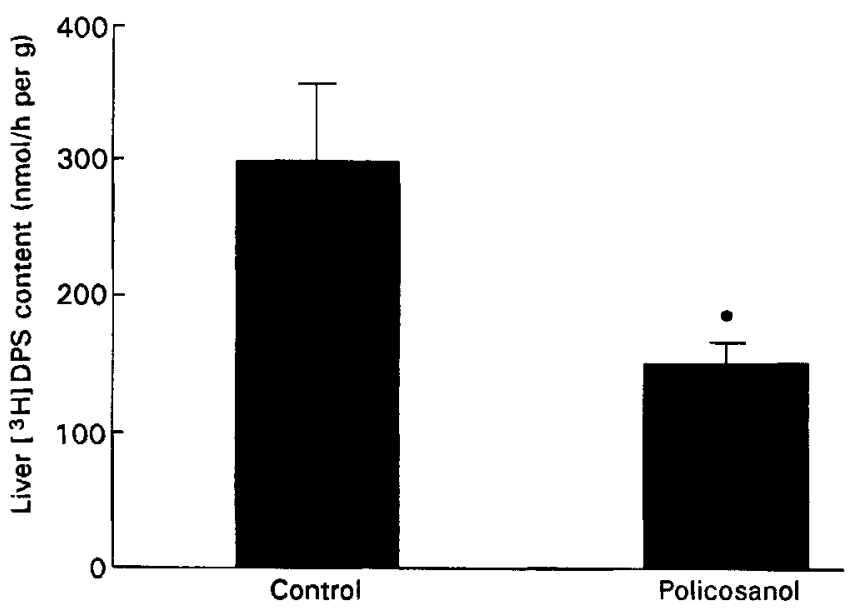

Fig. 1. Content of newly synthesized sterol (measured as digitonin-precipitable sterols, DPS) in liver of control and policosanol-treated rabbits fed on a wheat starch-casein diet. Values are means and standard deviations of five animals. * Mean value was significantly different from that of the control, $P<0.05$ (Mann-Whitney $U$ test).

Fig. 2 shows that the clearance of $\left[{ }^{125} \mathrm{I}\right] \mathrm{LDL}$ from the plasma of control hypercholesterolaemic rabbits was slower than that observed in the treated animals. The LDL kinetic parameters calculated from the radioactivity decay curves showed that the clearance of LDL for the rabbits treated with policosanol was considerably faster than the decline of radioactivity observed in the control group. Thus, $t_{1 / 2}$ was significantly reduced in the treated rabbits when compared with controls (12.6 (SD 1.03) h v. 59.5 (SD 12.42) h, $P<0.05)$.

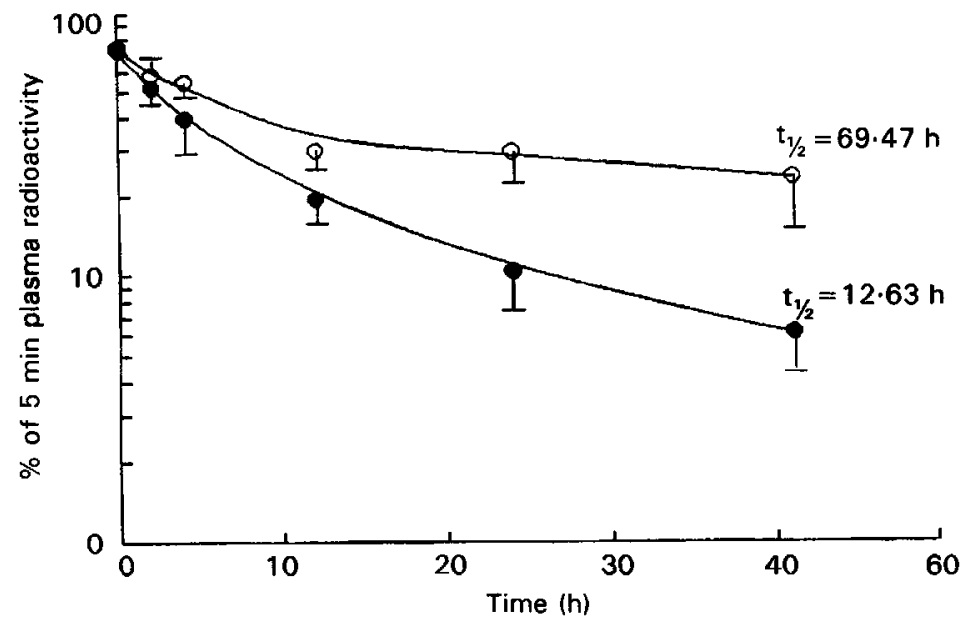

Fig. 2. The decline of plasma radioactivity following the injection of ${ }^{125}$ I-native-LDL into controls $(O)$ and policosanoltreated $(O)$ casein-fed rabbits. Each point represents the precipitable-associated radioactivity expressed as percentage of the level $5 \mathrm{~min}$ after injection of radio-iodinated LDL. Values are means and standard deviations for four animals per experimental group. 
Table 3. Effect of policosanol on the heparin-sensitive binding of $\left[^{125} I\right] L D L$ in rabbit liver homogenates $\dagger$

(Mean values and standard deviations for homogenates from five rabbits measured in triplicate)

\begin{tabular}{|c|c|c|c|}
\hline \multirow[b]{2}{*}{ Source of homogenates } & \multirow{2}{*}{$\begin{array}{c}\left.{ }^{125} \mathrm{I}\right] \mathrm{LDL} \text { added } \\
(\mu \mathrm{g} / \mathrm{ml})\end{array}$} & \multicolumn{2}{|c|}{$\begin{array}{c}{\left[{ }^{125} \text { I]LDL binding }\right.} \\
\text { (ng/mg protein) }\end{array}$} \\
\hline & & Mean & SD \\
\hline Control rabbits & $12 \cdot 5$ & 4.00 & 0.77 \\
\hline Policosanol treated & $12 \cdot 5$ & $22.08 *$ & $3 \cdot 40$ \\
\hline Control rabbits & $25 \cdot 0$ & 5.00 & 0.77 \\
\hline Policosanol treated & $25 \cdot 0$ & $31.85^{*}$ & $6 \cdot 46$ \\
\hline
\end{tabular}

* Mean values were significantly different from those for controls, $P<0.05$ (Mann-Whitney $U$ test).

$\uparrow$ For details of diet and procedures, see pp. 924-925.

Since most plasma cholesterol is internalized into cells by LDL through a well-defined LDL-receptor pathway (Brown \& Goldstein, 1986), we investigated the hypothesis that enhancement of LDL clearance is related to increased LDL-receptor activity in hepatic tissue, by determining the binding of labelled LDL to liver homogenates. In these experiments the heparin-releasable binding sites of liver homogenates from hypercholesterolaemic control rabbits were almost abolished, while LDL-binding sites were present in liver homogenates from rabbits treated with policosanol (Table 3).

\section{DISCUSSION}

Our results show that oral treatment with policosanol $(50 \mathrm{mg} / \mathrm{kg})$ for $30 \mathrm{~d}$ significantly reduced hypercholesterolaemia induced in rabbits by a wheat starch-casein diet. Policosanol diminished the increases in serum total and LDL-cholesterol induced by the diet, but levels of triacylglycerols and HDL-cholesterol (HDL-C) were not significantly affected.

Normal rabbits became hypercholesterolaemic when fed on a cholesterol-free wheat starch-casein diet. Since this diet is free of cholesterol, the hypercholesterolaemia is believed to be related to enhanced cholesterol biosynthesis (Kroon et al. 1982; Scholz et al. 1982), although controversial data on this subject exist (Carroll, 1971; Beynen et al. 1986; Khosla et al. 1991). It has been proposed that casein induces a rise in LDL concentration by stimulating cholesterol and/or bile acid absorption at the level of the gut. This increases the content of cholesterol in liver leading to a down-regulation of LDL-receptors and later to an increase in the output of cholesterol associated with this lipoprotein (Samman et al. 1989; Khosla et al. 1991).

Effects of cholesterol-lowering compounds that act through an inhibition of cholesterol biosynthesis have been examined using this rabbit model. An effective inhibitor of hydroxymethylglutaryl (HMG) CoA reductase (EC 1.1.1.88) such as mevinolin, prevented hypercholesterolaemia in rabbits fed on a casein-rich diet by raising the catabolic removal rate of plasma LDL in response to an increase in LDL-receptor activity (Chao et al. 1983).

The present study also showed that policosanol inhibited hepatic cholesterol biosynthesis, since ${ }^{3} \mathrm{H}_{2} \mathrm{O}$ incorporation into hepatic DPS was significantly depressed, by about $50 \%$, after policosanol administration. Also, after policosanol administration, a higher removal of $\left[{ }^{125} \mathrm{I}\right] \mathrm{LDL}$ from plasma was observed. We therefore considered the possibility that the observed enhancement of the LDL clearance could be due to increased 
hepatic LDL-receptor activity. In support of this hypothesis, we observed that in rabbits given policosanol, there was an increase in the heparin-sensitive binding of $\left[{ }^{125} \mathrm{I}\right] \mathrm{LDL}$ in comparison with the specific receptor activity seen in casein-fed rabbits not treated with policosanol. Furthermore, the increased LDL removal achieved by policosanol is consistent with the proportional increase in the number of receptors for LDL in liver homogenates. Taken together, these findings suggest that the enhancement of the LDL clearance could be due, at least in part, to increased LDL uptake by the liver.

However, the fact that ${ }^{125}$ I-radiolabelled native LDL can be metabolized via either the receptor mediated process or the receptor-independent pathway, requires the measurement of the effect of policosanol on the LDL catabolism via each of these processes. In this regard, future experiments will need to investigate the metabolism of radiolabelled native and modified LDL after policosanol treatment, to show more clearly whether the LDLcatabolism induced by policosanol is exclusively due to an effect on the receptordependent route.

Rabbits fed on casein protein show a tendency to increase LDL apo B production via the VLDL-independent pathway (Khosla et al. 1989; Samman et al. 1989). Although it is clear that the primary response to a casein diet is a decrease in the number of hepatic LDL receptors and not an increase in LDL apo B synthetic rate, we cannot rule out an effect of policosanol on the LDL apo B production rate. If this exists, policosanol might also decrease the LDL-C level in plasma by inhibiting the secretion of lipoprotein by the liver.

It has been proposed that casein-induced hypercholesterolaemia involves stimulation of cholesterol and/or bile acid absorption from the gut (Samman et al. 1989; Khosla et al. 1991). A corollary of this would be that inhibition of cholesterol and/or bile acid absorption from the gut by policosanol also could decrease this hypercholesterolaemia. The possibility remains open, since the effect of policosanol on intestinal absorption of cholesterol and excretion of faecal bile acids was not investigated. However, several findings argue against this effect. First, reduction of cholesterol and bile acid absorption can block diet-induced rises in serum cholesterol as reported previously (Topping, 1991; de Deckere et al. 1993; McCarthy, 1993; Nielsen et al. 1993). However, previous experiments performed in our laboratory have demonstrated that policosanol orally administered does not effectively prevent hypercholesterolaemia in cholesterol-fed rabbits (Noa et al. 1997). Second, Kato et al. (1995) found that the dietary incorporation of octacosanol into a high-fat diet did not affect lipid absorption from the gut in rats. All these findings suggest that factors other than an inhibition of cholesterol and/or bile acid absorption from the gut regulate LDL-receptor activity in the liver after policosanol administration.

To our knowledge, there are few studies on the absorption and metabolism of verylong-chain alcohols. Studies carried out after oral administration of the ${ }^{14} \mathrm{C}$-labelled compound to rats show that octacosanol absorption is limited, but that which is absorbed is distributed between several tissues and may be partially degraded to fatty acids (Kabir \& Kamura, 1993). We have obtained similar findings in kinetic studies using ${ }^{3} \mathrm{H}$-labelled octacosanol. In addition, we have demonstrated that the radioactivity is mainly present in liver within the first $24 \mathrm{~h}$ after oral administration and we also identified octacosanoic acid in liver early after oral administration of octacosanol (R. Menéndez, R. Más, V. Fraga, A. M. Amor, R. M. González, L. González, J. Magraner, D. Marrero, S. Jiménez and R. Gámez, unpublished results). Experiments performed by Rizzo et al. $(1988,1990)$ and Kosuke et al. (1986) have demonstrated that fatty alcohol oxidation can be produced in cultured cells and intestinal mucosa via a reversible fatty alcohol cycle. Recent experiments by Kawamura et al. (1981), Singh \& Poulos (1986), Singh et al. (1987) and Wanders et al. (1987) have shown that $\beta$-oxidative chain shortening of very-long-chain 
fatty acids (VLCFA) occurs in rat liver peroxisomes. Therefore, although this present study cannot demonstrate the exact mechanism for the policosanol-induced inhibition of hepatic cholesterol biosynthesis and increase of LDL receptor activity in casein-fed rabbits, the available data are consistent with the hypothesis that changes in hepatic cholesterol metabolism are mainly caused by the presence not only of aliphatic alcohols but also of VLCFA and chain-shortened secondary metabolites. Further research on the metabolism of policosanol may help determine the primary causes of its effects on casein-induced hypercholesterolaemia.

In conclusion, this work demonstrates that policosanol reduces the hypercholesterolaemia induced by a wheat starch-casein diet in rabbits, and that one of the actions of policosanol is that it prevents the loss of hepatic LDL receptors. According to our results, oral administration of policosanol also reduces the synthesis of cholesterol in the liver. However, since the hypercholesterolaemia induced by casein-feeding of rabbits also involves an increase in LDL synthesis rate, additional experiments must be performed to elucidate the effect of policosanol on LDL synthesis by the liver.

\section{REFERENCES}

Aneiros, E., Calderón, B., Más, R., Illnait, J., Castaf̃o, G., Fernández, L. \& Fernández, J. C. (1993). Effects of successive dose increases of policosanol on the lipid profile and tolerability of treatment. Current Therapeutic Research 54, 304-312.

Aneiros, E., Más, R., Calderón, B., Illnait, J., Fernández, L., Castaño, G. \& Fernández, J. C. (1995). Effect of policosanol in lowering-cholesterol levels in patients with type II hypercholesterolemia. Current Therapeutic Research 56, 176-182.

Arruzazabala, L., Carbajal, D., Más, R., Molina, V., Valdés, S. \& Laguna, A. (1994). Cholesterol-lowering effects of policosanol on normocholesterolemic rabbits. Biological Research 27, 205-208.

Beynen, A. C., Van der Meer, R. \& West, C. E. (1986). Mechanism of casein-induced hypercholesterolemia: primary and secondary features. Atherosclerosis 60, 291-293.

Brown, M. \& Goldstein, J. (1986). A receptor-mediated pathway for cholesterol homeostasis. Science 232, 3447.

Canadian Council of Animal Care (1980). Guide to the Care and Use of Experimental Animals. Ottawa: Canadian Council of Animal Care.

Canetti, M., Moreira, M., Illnait, J., Más, R., Fernández, L., Castaño, G. \& Fernández, J. C. (1995). One-year study on the effect of policosanol ( $5 \mathrm{mg}$ twice-a-day) on lipid profile in patients with type II hypercholesterolemia. Advances in Therapy 12, 245-254.

Carroll, K. K. (1971). Plasma cholesterol and liver cholesterol biosynthesis in rabbits fed commercial or semisynthetic diet with and without added fats or oils. Atherosclerosis 13, 67-76.

Castaño, G., Canetti, M., Moreira, M., Tula, L., Más, R., Illnait, J., Fernández, L. \& Fernández, J. C. (1995a). The efficacy and tolerability of policosanol $(10 \mathrm{mg} /$ day $)$ in elderly patients with type II hypercholesterolemia: a one-year study. Current Therapeutic Research 56, 819-828.

Castaño, G., Más, R., Nodarse, M., Illnait, J., Fernández, L. \& Fernández, J. C. (1995b). One-year study of the efficacy and safety of policosanol ( $5 \mathrm{mg}$ twice-a-day) in the treatment of type II hypercholesterolemia. Current Therapeutic Research 56, 296-304.

Chao, Y., Kroon, P. A., Yamin, T. T., Thompson, G. M. \& Alberts, A. W. (1983). Regulation of hepatic receptor-dependent degradation of LDL by mevinolin in rabbits with hypercholesterolemia induced by a wheat starch-casein diet. Biochimica et Biophysica Acta 754, 134-141.

Cruz-Bustillo, D., Mederos, D., Más, R., Arruzazabala, L., Laguna, A., Barreto, D. \& Martinez, O. (1991). Efecto hipocolesterolemico del Ateromixol (PPG) sobre el cerdo en ceba (Cholesterol-lowering effect of Ateromixol (PPG) on fattening hogs). Revista CENIC Ciencias Biológicas 22, 62-63.

de Deckere, E. A. M., Kloots, W. J. \& van Amelsvoort, J. M. M. (1993). Resistant starch decreases serum total cholesterol and triacylglycerol concentrations in rats. Journal of Nutrition 123, 2142-2151.

Havel, R. J., Elder, H. A. \& Bragdon, J. A. (1955). The distribution and chemical composition of ultracentrifugally separated lipoproteins in human serum. Journal of Clinical Investigation 34, 345-348.

Hernández, G., Illnait, J., Más, R., Castaño, G., Fernández, L., González, M., Cordovi, N. \& Fernández, J. C. (1993). Effects of policosanol on serum lipids and lipoproteins in healthy volunteers. Current Therapeutic Research 51, 568-575.

Jeske, D. J. \& Dietschy, J. M. (1980). Regulation of rates of cholesterol synthesis in vivo in the liver and carcass of the rat measured using $\left[{ }^{3} \mathrm{H}\right]$-water. Journal of Lipid Research 21, 364-376. 
Kabir, Y. \& Kimura, S. (1993). Biodistribution and metabolism of orally administered octacosanol in rats. Annals of Nutrition and Metabolism 37, 33-38.

Kato, S., Karino, K., Hasegawa, S., Nagasawa, J., Nagasaki, A., Eguchi, M., Ichinose, T., Tago, K., Okumori, H. \& Hamatani, K. (1995). Octacosanol affects lipid metabolism in rats fed on a high-fat diet. British Journal of Nutrition 73, 433-441.

Kawamura, N., Moser, H. W. \& Kishimoto, Y. (1981). Very long chain fatty oxidation in rat liver. Biochemical and Biophysical Research Communications 99, 1216-1225.

Khosla, P., Samman, S. \& Carroll, K. K. (1991). Decreased receptor-mediated LDL catabolism in casein-fed rabbits precedes the increase in plasma cholesterol levels. Journal of Nutritional Biochemistry 2, $203-209$.

Khosla, P., Samman, S., Carroll, K. K. \& Huff, M. W. (1989). Tumover of ${ }^{125} \mathrm{I}-\mathrm{VLDL}$ and ${ }^{131} \mathrm{I}-\mathrm{LDL}$ apolipoprotein B in rabbits fed diets containing casein or soy protein. Biochimica et Biophysica Acta $\mathbf{1 0 0 2}$, 157-163.

Kosuke, J., Kusunose, E., Noda, Y. \& Kusunose, M. (1986). Some properties of the fatty alcohol system and reconstitution of microsomal oxidation activity in intestinal mucosa. Biochimica et Biophysica Acta 878, 412418.

Kroon, P. A., Hand, K. M., Huff, J. W. \& Alberts, A. W. (1982). The effects of mevinolin on serum cholesterol levels of rabbits with endogenous hypercholesterolemia. Atherosclerosis 44, 41-49.

Lowry, O. H., Rosebrough, N. J., Farr, A. L. \& Randall, R. J. (1951). Protein measurement with the Folin phenol reagent. Journal of Biological Chemistry 193, 265-275.

McCarthy, P. A. (1993). New approaches to atherosclerosis: an overview. Medicinal Research Reviews 2, 139159.

McFarlane, A. S. (1958). Efficient tracer labelling with iodine. Nature 182, 53-57.

Menéndez, R., Femández, I., del Rio, A, González, R., Fraga, V., Amor, A. \& Más, R. (1994). Policosanol inhibits cholesterol biosynthesis and enhances LDL processing in cultured human fibroblasts. Biological Research 27, 199-203.

Menéndez, R., Fraga, V., Sotolongo, V., Amor, A., del Rio, A., González, R., Jimenez, S. \& Más, R. (1993). Efecto del policosanol sobre el metabolismo lipidico en ratas normocolesterolemicas (Effect of policosanol on lipid metabolism of normocholesterolaemic rats). Revista Mexicana de Ciencias Farmacéuticas 24, 16-18.

Nielsen, L. B., Stender, S. \& Kjeldsen, K. (1993). Effect of lovastatin on cholesterol absorption in cholesterolfed rabbits. Pharmacology and Toxicology 72, 148-151.

Noa, M., Arruzazabala, L., Carbajal, D., Más, R. \& Illnait, J. (1997). Efectos del policosanol sobre la hipercolesteromia exógena en conejos (Effect of policosanol on cholesterol-fed rabbits). Revista CNIC Ciencias Biológicas (In the Press).

Notari, R. (1980). Pharmacokinetic parameters. In Biopharmaceuticals and Clinical Pharmacokinetics: An Introduction, 3rd ed., p. 45. New York and Basel: Marcel Dekker, Inc.

Pons, P., Más, R., Illnait, J., Fernández, L., Rodríguez, M., Robaina, C. \& Fernández, J. C. (1992). Efficacy and safety of policosanol in patients with primary hypercholesterolemia. Current Therapeutic Research 52, 507513.

Pons, P., Rodríguez, M., Robaina, C., Illnait, J., Más, R., Fernández, L. \& Fernández, J. C. (1994). Effect of successive dose increase of policosanol on the lipid profile of patients with type II hypercholesterolemia and tolerability to treatment. Journal of Clinical Pharmacological Research 14, 27-33.

Rizzo, E., Craft, D., Dammann, A. \& Phillips, M. (1990). Fatty alcohol metabolism in cultured fibroblasts. Evidence for a fatty alcohol cycle. Journal of Biological Chemistry 262, 17412-17419.

Rizzo, W., Dammann, A. \& Craft, D. (1988). Sjögre-Larsson syndrome. Impaired fatty alcohol oxidation in cultured fibroblasts due to a deficient fatty alcohol:nicotinamide adenine nucleotide oxidoreductase activity. Journal of Clinical Investigation 81, 738-744.

Rodríguez-Echenique, C., Mesa, R., Más, R., Noa, M., Menéndez, R., González, R. M., Amor, A. M., Fraga, V., Sotolongo, V. \& Laguna, A. (1994). Effect of policosanol chronically administered in male monkeys (Maccaca arctoides). Food and Chemical Toxicology 32, 565-575.

Rudling, M. J. \& Peterson, C. O. (1985a). A simple binding assay for determination of low-density lipoprotein receptors in cell homogenates. Biochimica et Biophysica Acta 833, 359-365.

Rudling, M. J. \& Peterson, C. O. (1985b). LDL receptors in bovine tissues assayed as the heparin-sensitive binding of ${ }^{125}$ I-labelled LDL in homogenates: relation between liver LDL receptors and serum cholesterol in fetus and post term. Biochimica et Biophysica Acta 836, 96-104.

Samman, S., Khosla, P. \& Carroll, K. K. (1989). Effects of casein and soy protein on metabolism of radiolabelled low density apolipoprotein B in rabbits. Lipids 24, 169-171.

Scholz, K. E., Beynen, A. C. \& West, C. E. (1982). Comparison between the hypercholesterolemia in rabbits induced by semipurified diets containing either cholesterol or casein. Atherosclerosis 44, 85-97.

Singh, H., Derwas, N. \& Poulos, A. A. (1987). Very long chain fatty acid $\beta$-oxidation by rat liver mitochondria and peroxisomes. Archives of Biochemistry and Biophysics 359, 382-390.

Singh, H. \& Poulos, A. A. (1986). A comparative study of stearic acid and lignoceric acid oxidation by human skin fibroblasts. Archives of Biochemistry and Biophysics 250, 171-179. 
Soltero, I., Fuentemayor, I. \& Colmerares, J. (1993). Estudio comparativo doble ciego de la eficacia y tolerancia del policosanol Vs bezafibrato en pacientes con hiperlipidemias tipo II (A double-blind comparative study of the effectiveness and tolerability of policosanol vs bezafibrate on type II hyperlipidaemic patients). Archivos Venezolanos de Farmacolgia y Terapéutica 12, 65-70.

Spady, D. K. \& Dietschy, J. M. (1983). Sterol synthesis in vivo in 18 tissues of the squirrel monkey, guinea pig, rabbit, hamster and rat. Journal of Lipid Research 24, 303-315.

Terpstra, A. H. M., Woodward, C. J. H. \& Sánchez-Muñiz, F. J. (1981). Improved techniques for the separation of serum lipoproteins by density gradient ultracentrifugation: visualization by prestaining and rapid separation of serum lipoproteins from small volumes of serum. Analytical Biochemistry 111, 157-159.

Topping, D. L. (1991). Soluble-fiber polysaccharides-effects on plasma cholesterol and colonic fermentation. Nutrition Reviews 49, 195-203.

Torres, O., Agramonte, A. J., Illnait, J., Fernández, L. \& Fernández, J. C. (1995). Treatment of hypercholesterolemia in NIDDM with policosanol. Diabetes Care 18, 393-397.

Wanders, R. J. A., van Roermund, C. W. T., van Wijland, M. J. A., Schutgens, R. B. H., Scham, A. W., van den Bosch, H. \& Tager, J. M. (1987). Studies on the peroxisomal oxidation of palmitate and lignocerate in rat liver. Biochimica et Biophysica Acta 919, 21-25. 